Hacettepe Üniversitesi İktisadi ve İdari Bilimler Fakültesi Dergisi

Hacettepe University Journal of Economics and Administrative Sciences

https://dergipark.org.tr/tr/pub/huniibf

ISSN:1301-8752 E-ISSN:1309-6338

Başvuru Tarihi / Submission Date: 10.11.2020

DOI: $10.17065 /$ huniibf.823845

Kabul Tarihi / Acceptance Date: 21.04.2021

2021, 39(3), 359-378

\title{
Is Production or Consumption the Determiner? Sources of Turkey's CO2 Emissions between 1990-2015 and Policy Implications
}

Ayla Alkan ${ }^{1}$, Ayla Oğuş Binatı

\begin{abstract}
Turkey's CO2 emissions have been steadily increasing since the 1990s. Determining influences of socioeconomic factors behind this increase can help identify which sectors and what types of policies should be prioritized to go into action. This paper identifies the main contributors to $\mathrm{CO} 2$ emissions change within five-year intervals during 1990-2015 by adopting the Structural Decomposition Analysis (SDA) method. The results show that $\mathrm{CO} 2$ emissions increase was driven by per capita expenditure and population factors, while emission coefficient factor had a reducing effect on emissions. As the production side factors fell pretty behind the consumption side factors, net emissions were positive and the actual determiner in $\mathrm{CO} 2$ emissions was found as consumption. The most contributing sectors were Electricity, Land Transportation and Mineral. Speeding up renewable energy investments and continuing energy efficiency measures, placing a carbon tax on electricity and oil consumption, promoting public transport and use of clean fuels and vehicles, slowing down construction and raising consumer awareness to change their consumption behavior, particularly to reduce demand for high emitting products and services should be the top priority policies.
\end{abstract}

Keywords: Supply-use table; structural decomposition analysis; CO2 emission; INDC; Turkey.

\section{Üretim mi, Tüketim mi Belirleyici? 1990-2015 yıllarında Türkiye CO2 Emisyonlarının Kaynakları ve Politika Etkileri}

Öz

Türkiye'nin CO2 emisyonları 1990'dan beri istikrarlı bir şekilde artmaktadır. Bu artışın arkasındaki sosyoekonomik faktörlerin etkilerinin belirlenmesi, eyleme geçmek için hangi sektörlere ve hangi tür politikalara öncelik verilmesi gerektiğini belirlemeye yardımcı olabilir. Bu çalışma, Yapısal Ayrıştırma Analizi metodunu kullanarak 1990-2015 döneminde beş yıllık aralıklarla CO2 emisyon değişimine başııa katkı yapan faktörleri tanımlamaktadır. Sonuçlar, CO2 emisyon artışının kişi başına harcama ve nüfus faktörlerinden kaynaklandığını, emisyon katsayııı faktörünün ise emisyonu azaltııı bir etkiye sahip olduğunu göstermektedir. Üretim tarafı faktörleri tüketim tarafı faktörlerinin oldukça gerisinde kaldığı için net emisyon pozitif olmuş ve $\mathrm{CO} 2$ emisyonundaki asıl belirleyici tüketim olarak bulunmuştur. En çok katkıda bulunan sektörler Elektrik, Kara Taşımacılığı ve Mineral olmuştur. Yenilenebilir enerji yatııılarını hızlandırmak ve enerji verimliliği önlemlerini sürdürmek, elektrik ve petrol tüketimine karbon vergisi koymak, toplu taşımayı ve temiz yakıt ve araç kullanımın teşvik etmek, inşaatı yavaşlatmak ve tüketim davranışlarını değiştirmek, özellikle de yüksek emisyonlu ürün ve hizmetlere olan talebi azaltmak için tüketici bilincini artırmak en öncelikli politikalar olmalıdır.

Anahtar Kelimeler: Arz-kullanım tablosu, yapısal ayrıştırma analizi, CO2 emisyonu, INDC, Türkiye.

\footnotetext{
${ }^{1}$ Corresponding Author (Sorumlu Yazar), Assist. Prof., Beykent University, Department of Industrial Engineering, aylaalkan@beykent.edu.tr, https://orcid.org/0000-0001-8574-6052

2 Prof. Dr., Izmir University of Economics, Department of Economics, ayla.ogus@ieu.edu.tr, https://orcid.org/0000-0002-8291-0010
} 


\section{INTRODUCTION}

Climate change is a global risk that continues to evade political resolution. The World Development Report-2010 states that solution necessitates a transformation requiring to act now, together, and differently (Bierbaum, Fay, and Ross-Larson, 2009). Turkey, as a developing country, had $2.9 \%$ share in total greenhouse gas (GHG) emissions by Annex-1 Parties to the United Nations of Climate Change Convention (UNFCCC) in 2016 (UNFCCC, 2020) and its historical contribution to atmospheric accumulation of GHG emissions is extremely low, 0.7\% (Republic of Turkey, 2015). Between 1990 and 2015, CO2 emissions increased 2.15 times (CO2 emissions (kt)- World Bank, 2020a) while GDP increased 2.98 times (GDP (constant 2010 US\$)- World Bank, 2020a). In 2015, population was 1.46 times that of population in 1990 (Population, total- World Bank, 2020a). The continuous increase in Turkey's CO2 emissions (120\% in 1990-2015) is perturbative, especially in contrast to reductions that have been seen in the EU (-21\%), USA (3\%), and average of High Income (HI) (8\%) countries since 2006. The upward trend of $\mathrm{CO} 2$ emissions in Turkey (an Upper Middle Income Country (UMI) (World Bank, 2020b)) is also more aggressive than UMI countries average (88\%), but not as much as those seen in China $(253 \%)$ and India (149\%) (see Figure 1 panel a). $\mathrm{CO} 2$ emission per capita was 4.5 ton $(0.0045 \mathrm{Gg})$ per capita in 2014 which was still less than the USA, China, and most of the EU countries (CO2 emissions (metric tons per capita)- World Bank, 2020a).

After the Kyoto Protocol it took ten years to reach a new climate agreement, and the negotiations have eventually culminated in the Paris Agreement. The main objective of the agreement is to keep the global temperature below 1.5 or 2 degrees Celsius above pre-industrial levels, recognizing that is the limit of safety to protect the planet against droughts, heatwaves, floods, and sea level rises (UNFCCC, 2016). Its power is in banding together the developed and developing countries, and forcing them to submit Intended Nationally Determined Contributions (INDCs).

In its INDC, Turkey intended an emissions reduction target that is $21 \%$ lower than the business as usual scenario by 2030 (Republic of Turkey, 2015). Turkey signed the agreement in 2016 but has not ratified it yet. Implementation period started in 2020 and will end in 2030. Turkey also states that it is responsible for only $0.7 \%$ of the accumulated global emissions, and it should continue its development. Emphasizing eligibility to developmental assistance, special circumstances that placed it in a different situation than the other Parties in Annex 1, and its national circumstances and capabilities, Turkey stated its intention as to contribute to the collective efforts to combat climate change. Turkish INDC document comprised only mitigation issue, included all types of GHGs, comprised absorptivity of Land Use and Land Use Change (LULUCF), and set a target taking a business as usual scenario as base.

The actions planned in the energy sector are fully utilizing the country's limited energy resources (utilizing all coal reserves and all hydroelectric potential), constructing nuclear power plants, increasing renewable energy supply, and increasing efficiency in electricity transmission and distribution. The actions in the energy sector in the INDC document were not only the most numerous but also the only measurable goals, such that Alkan, Oğuş-Binatlı, and Değer (2018) were able to generate only three shocks from the INDC, and all of them were from the energy sector. The goals in transportation sector can be summarized as promoting public transport, and use of alternative fuels and clean vehicles, and increasing shares of railway and waterway transport modes. Some of these goals were repetitive and did not have quantitative targets or clear deadlines. Constructing energy-efficient buildings in the buildings and urbanization sector; land consolidation, efficient fertilizer use, rehabilitation of grazing lands, and implementing modern agricultural activities in the agriculture sector; and promoting recycling, increasing number of managed landfill sites, and using waste as an alternative fuel in the waste sector were the remaining stereotyped, unmeasurable and unexamined solutions in the INDC. Furthermore, the $21 \%$-mitigation target is shown to be implausible by Alkan et al. (2018), Karapinar, Dudu, Geyik, and Yakut (2019), Acar et al. (2016), and Kat, Paltsev and Yuan (2018).

After submitting its INDC, Turkey prepared its Joint First and Second Biennial Report ${ }^{1}$ and Sixth National Communication ${ }^{2}$ in 2016, its Third Biennial Report and Seventh National Communication in 2018, and Fourth Biennial Report in 2020. Turkey continues to publish emissions, carbon sinks and capture, 
precipitation, temperature, and sea surface temperature statistics annually. Between 2015 and 2020, Turkey has not prepared any new national document with a sole focus on combating climate change, and only mentions climate change in its development plans and strategy documents.

GHG emissions of Turkey in 2015 primarily originated from the energy sector (71.58\%); followed by industrial processes $(12.78 \%)$, the agriculture sector $(12.08 \%)$, and the waste sector (3.56\%) (Turkish Statistical Institute (Turkstat), 2017) (see Figure 1 panel b). When only CO2 gas emissions are considered, $86.14 \%$ was from energy sector and $13.65 \%$ was from industry sector, and agriculture and waste sectors did not contribute significant amounts to total CO2 emissions (Turkstat, 2017) (see Figure 1 panel c). Total CO2 emissions increased at a rate of \%159 in the 1990-2015 period. The energy sector grew more than this rate, by $163 \%$. As referred in National Inventory Reports, the energy sector includes GHG emissions from combustion of fossil fuels and fugitive emissions from fossil fuels' transportation and storage. Industry sector CO2 emissions grew by $139 \%$ in the same 25 -year period. Industry sector GHG emissions are released during manufacturing processes, but the gases released from fuel combustion which is for supplying energy to manufacturing processes are counted in energy sector, not in industry sector. The mineral industry contributed $62.1 \%$, the metal industry contributed $19.42 \%$, product uses as ODS substitutes contributed $7.91 \%$, and the chemical industry contributed $6.87 \%$ of the total GHG emissions from industrial processes and product use sector in 2015 (Turkstat, 2017). The most contributing sector to total emissions has always been the energy sector with a high growth rate, however the increase in the industry sector was more significant especially after 2000 s.

The motivation in this study is to determine the factors behind the continuously increasing $\mathrm{CO} 2$ emissions in Turkey, particularly to understand whether production or consumption side factors are determinative. This study analyzed 1990-2015 period in 5 year-intervals by employing Structural Decomposition Analysis (SDA) method and identified five driving factors to get the most from the data: emissions coefficient, technology, final demand structure, per capita expenditure, and population. Singleregion Input Output Tables (IOs) tables were taken from the Eora database in the form of Supply-Use Tables (SUTs) (59 sectors), and CO2 emissions were added as a satellite account.

In the rest of this paper, section 1 is reviewing the related literature, section 2 is describing the data sources and the methodology, section 3 is presenting the results and carrying out a discussion and section 4 is addressing conclusion and policy suggestions. 


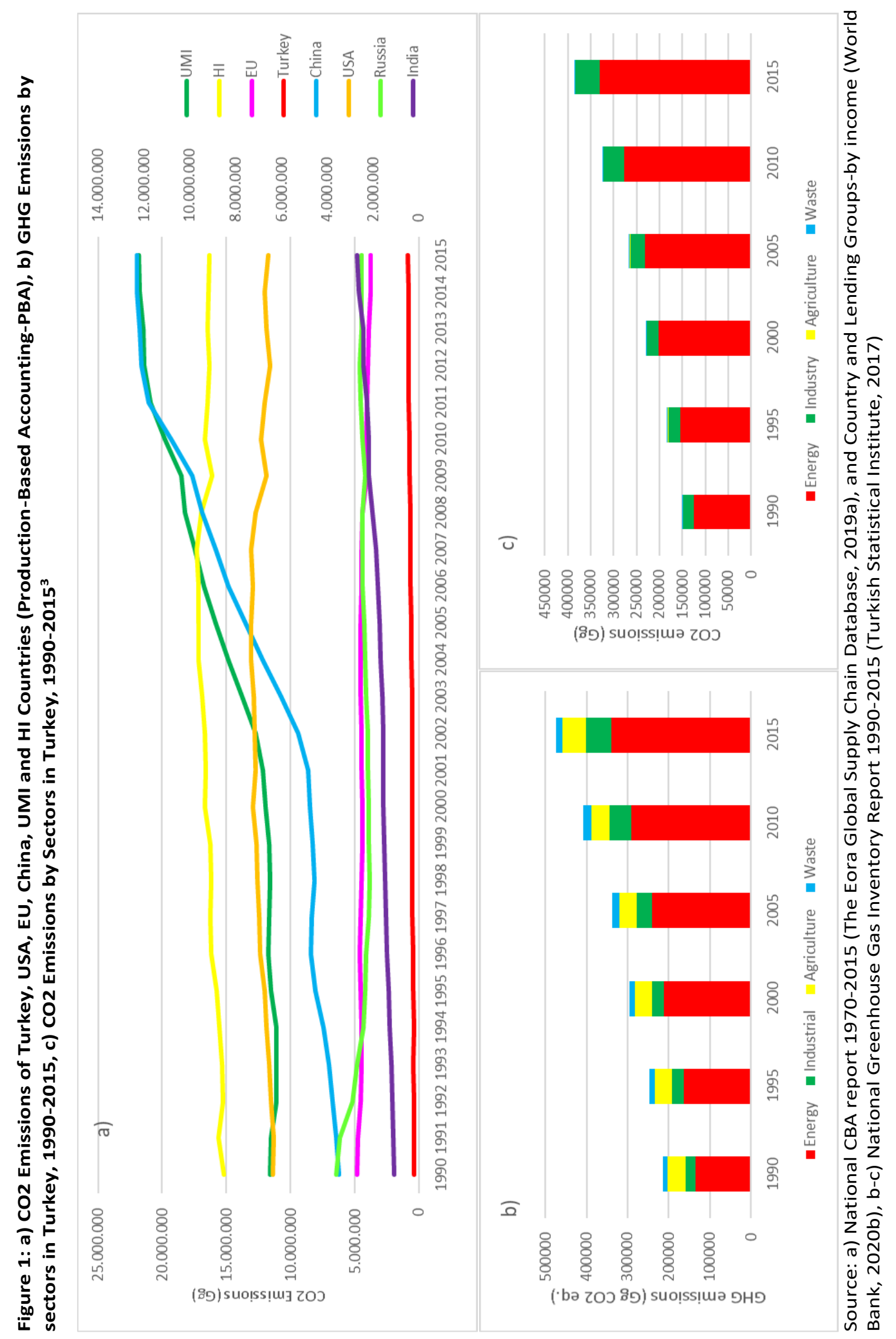




\section{LITERATURE REVIEW}

Decomposition methods are frequently used to identify the drivers of energy or environment related magnitudes such as energy consumption, pollutant emissions, $\mathrm{CO} 2$ emissions which help more efficient policy making. ${ }^{4}$ Findings of most recent decomposition studies at the global level showed that income is the primary driver of carbon emissions increases and population is the second driver increasing emissions while progress in technology and energy intensity ${ }^{5}$ acted to curb emissions (Arto and Dietzenbacher, 2014; Chang, Dong, Sui and Chu, 2019; Dong, Jiang, Sun and Dong, 2019; Xia, Wang, Liu and Pan, 2020). About contribution of another generally studied factor, carbon intensity, Xia et al., (2020) found that its contribution remained very small starting in the 2000s and gradually became negative up to 2017 which is in contrast to the positive contribution found in Chang et al. (2019). Dong et al. (2019) decomposed $\mathrm{CO} 2$ emissions of High Income (HI), Upper Middle Income (UMI), Lower Middle Income (LMI) and Lower Income (LI) country groups (World Bank, 2020b) from 1980 through 2015 with LMDI method. In both $\mathrm{HI}$ and UMI countries, while income was the most contributing factor, energy intensity was the main offsetting factor. Population ranked second in contribution to emissions growth in both country groups, but emission coefficient was another significant factor resulting in increase in UMI countries' emissions. China, USA, EU, India and Russia are the top most contributing countries with \%61.58 of global emissions rate in 2015 (The Eora Global Supply Chain Database, 2019b) and are listed in HI or UMI countries except India (LMI). China's $\mathrm{CO} 2$ emissions increases were driven by economic development and population (Zheng et al. 2020), but since 2012, the beginning of the new normal economy, emissions showed a plateauing trajectory which was driven by improvements in energy intensity (Zheng, Mi, Coffman, Shan, Guan and Wang 2019). As an HI country and ranked second in global emissions, USA's emissions decrease by energy intensity and carbon intensity improvements, while income and population continued to increase emissions (Sesso, Amancio-Vieira, Zapparoli and Sesso Filho, 2020; Henriques and Borowiecki, 2017; Xia et al., 2020). EU which mostly comprises of HI countries realizes emissions reductions since the 2000s by improvements in energy intensity, but income and population factors have still increasing effect on its emissions (Sesso et al., 2020; Henriques and Borowiecki, 2017; Perrier, Guivarch, Boucher, 2019; Xia et al., 2020). In India and Russia, the other two most contributing countries, energy intensity was the primary mitigating factor, and while income acted to increase emissions in Russia, income and population together were resulting increase in India's emissions (Xia et al., 2020).

The recent decomposition studies for Turkey were made for different sectors, different years, and different length of time. A recent study by Isik, Sarica, and Ari (2020) employed Logarithmic Mean Divisia Index (LMDI) method to reveal the factors on $\mathrm{CO} 2$ emissions from transportation sector between 2000 and 2017, and found that economic growth is the principal driver, followed by population and emission intensity. Kim, Kim, Kim and Park (2020) used LMDI method to analyze electricity generation sector in 36 OECD countries in the periods 1995-2008 and 2008-2017, and showed that while European countries have significantly reduced carbon emissions from GDP growth through various policy efforts such as electricity intensity (demand), closing down of thermal generation (supply), and change in energy mix (supply), but non-European countries including Turkey could not have accomplished to reduce emissions from GDP growth. The study projected that GDP increased Turkey's $\mathrm{CO} 2$ emissions at a rate of $98 \%$ of net emissions increase, but efficiency in electricity generation which is on the supply side decreased emissions at $12 \%$ of net emission. Akbostancı, Tunç, and Türüt-Aşık (2018) made two decomposition analyses with LMDI method, one for GDP sectors (agriculture, forestry and fishery, manufacturing industries and construction, public electricity and heat production, transport and residential sectors) in 1990-2013 and one for manufacturing and construction sectors. They concluded that economic activity and energy intensity were the principal drivers of $\mathrm{CO} 2$ emissions in GDP sectors, manufacturing industriesconstruction and public electricity- heat production dominated the emissions change; and among the manufacturing industries and construction subsectors, the non-metallic minerals sector has the highest contribution to emissions followed by the chemicals sector. A more recent study by Karakaya, Bostan and Özçağ (2019) studied energy-related CO2 emissions trends in 1990-2016 by using Kaya Identity and LMDI methods, and the results indicated that economic growth and population effects are the main driving 
forces in increases in carbon emissions, while other technology-based driving factors' impacts are rather minimal in reducing the emissions. Köne and Büke (2019) used the Kaya Identitiy decomposition analysis on the historical (1971-2014) and projected (2015-2060) CO2 emissions from fossil fuel combustion in Turkey and found that growth and population were the main drivers in the past but their effect will be greatly reduced in the future.

Three main features of this paper distinguish it from previous decomposition analyses conducted for Turkey. First, our study uses input output tables which comprise the whole economic system and make it possible to take into account both direct and indirect demand effects (demand change in one sector indirectly leads to changes in demand of others). As production and consumption structures can shift in time and thus affect emissions, evaluating mitigation performance of past policies and making new policies can be made through the national supply change. Our study particularly investigates whether production or consumption side factors dominate emissions change and this is the main contribution of this paper. Other decomposition studies on Turkey considered one or a few sectors and did not make a distinction between consumption and production. Second, all prior decomposition studies analyzing Turkey's emissions employ LMDI (or other IDA methods), but our analysis will be the only study using the SDA method which provides a richer picture. Third, data used in this study comprises $\mathrm{CO} 2$ emissions for past 25 years with the most recent 10 tables extended to 2015. Such a comprehensive analysis is expected to provide a better understanding of $\mathrm{CO} 2$ emissions change for policy makers in Turkey.

\section{DATA AND METHOD}

\subsection{Data Sources}

Data of this study (IO tables, $\mathrm{CO} 2$ emissions, and population) was obtained from the Eora database (The Eora Global Supply Chain Database, 2019b). Turkey's IO tables are provided in SUT format for years 1970-2015. These SUTs consist 61 sectors; 59 sectors are the same with the sectors in the 200210 table published by Turkish Statistical Institute, and two other sectors are Re-export, and Financial Intermediary Services, Indirectly Measured (FISIM). As these two sectors caused unreasonable large deviations when SDA was applied, both were deleted from SUTs, and the analysis was made on the remaining 59 sectors.

An ordinary SUT structure and Turkey's SUT structure in the Eora database are shown in Table 1, and differently, Turkey's SUT includes import and export accounts. In Turkey's SUT, imports were provided in the industry accounts from 189 countries separately, and exports were provided in the commodity accounts to the same 189 countries. There was a Rest of World (ROW) country group aggregating imports from and exports to other countries for whom data was not separately provided. However, the ROW had import values both in the commodity accounts and in the industry accounts, and export values both in the industry accounts and in the commodity accounts. For the compliance with the import and export structure of the 189 individual countries, we added the import values from the ROW in the commodity accounts to the import values in the industry accounts; and the export values to the ROW in the industry accounts to the export values in the commodity accounts. Then, we summed up exports to all individual countries and to the ROW into one column and defined as total export, and summed up imports from all individual countries and from the ROW into one row, and defined as total import. We used import and export to balance the SUT tables. At last, we deflated the tables that are provided with the current-year prices ('000 USD) to 2010 year by using USD GDP deflator (USA-GDP deflator (base year varies by country)World Bank, 2020a).

The Eora database consists $\mathrm{CO} 2$ emissions inventories from two data providers: EDGAR and CDIAC. We use the EDGAR CO2 emissions since these are more in line with the official statistics. EDGAR CO2 emissions are provided in Gigagram (Gg) units. 
Table 1: An ordinary SUT structure and Turkey SUT structure in the Eora database

\begin{tabular}{|c|c|c|c|c|c|c|c|c|c|c|c|c|c|}
\hline \multicolumn{5}{|c|}{ a) Ordinary SUT } & \multicolumn{9}{|c|}{ b) Eora Turkey SUT } \\
\hline & Industry & Commodity & $\begin{array}{l}\text { Final } \\
\text { demand }\end{array}$ & Total & & Industry & Commodity & $\begin{array}{l}\text { Final } \\
\text { demand }\end{array}$ & Country A & Country B & $\ldots$ & ROW & Total \\
\hline Industry & & v & & $x$ & Industry & & v & & & & & E_ROW1 & $x$ \\
\hline Commodity & $u$ & & e & q & Commodity & $u$ & & e & $\mathrm{E}$ & & & E_ROW2 & $q$ \\
\hline Value added & $v^{\prime}$ & & & & Value added & $v^{\prime}$ & & & & & & & \\
\hline \multirow[t]{5}{*}{ Total } & $x^{\prime}$ & $q^{\prime}$ & & & Country A & M & & M_fin. & & & Nan & Nan & \\
\hline & & & & & Country B & & & & & & & & \\
\hline & & & & & $\ldots$ & & & & & & & & \\
\hline & & & & & ROW & M_ROW1 & M_ROW2 & & & & Nan & Nan & \\
\hline & & & & & Total & $x^{\prime}$ & $q^{\prime}$ & & & & & & \\
\hline
\end{tabular}

U: Use matrix (input matrix) purchases of commodities by industries (nxn); V: Make matrix (output matrix) output of commodities that are produced by industries (nxn); $\mathrm{x}$ : total industry output (nx1); q: total commodity output (nx1); e: commodity final demand (nx1); E: export from commodity accounts to "one" country (nx1); E ROW1: export from industry accounts to rest of world (ROW) (nx1); E_ROW2: export from commodity accounts to ROW (nx1); M: import to industry accounts from "one" country (1xn); M_fin.: import to final demand accounts from "one" country (1x1); M_ROW1: import to industry accounts from ROW (1xn); M_ROW2: import to commodity accounts from ROW (1xn). The detailed information about these matrices and vectors can be provided by the author upon request. 


\subsection{Structural Decomposition Analysis}

Structural Decomposition Analysis (SDA) is a decomposition method that reveals the roles that different economic sectors play in the growth of GHG emissions. SDA method has two alternative modes of decomposition: additive and multiplicative. The additive decomposes the change in one variable as a summation of changes in the components of that variable. Following an overwhelming majority of SDA studies (Su and Ang, 2012), we use the additive SDA in this paper.

There are various decomposition techniques for the additive SDA; namely ad hoc, the logarithmic mean Divisia index (LMDI-I and LMDI-II), the Dietzenbacher and Los (D\&L), the Shapley/Sun (S/S), and the mean rate of change index (MRCI) techniques. Su and Ang (2012) grouped 43 SDA studies conducted in the 1999-2010 period into four categories according to the techniques they used, ad hoc, D\&L, LMDI, and others, and the number of studies using D\&L, LMDI, ad hoc, and others were $23,5,11$, and 4, respectively. Thus, we used the $D \& L$ technique as it has a vast theoretical and empirical literature that eases application of the technique and increases comparability of the results.

SDA method is derived from the IO multiplier equation below:

$$
\mathrm{x}=(\mathrm{I}-\mathrm{A})^{-1} \mathrm{f}
$$

where $\mathrm{x}$ is $\mathrm{nx} 1$ and denotes the industry output of $\mathrm{n}$ sectors of the economy, (I-A) $)^{-1}$ term is the Leontief inverse, $L$, which is $n \times n$, and $f, n \times 1$, is a column vector of final demands. A denotes an $n \times n$ technical coefficients matrix, and $I$ is an $n \times n$ identity matrix.

Change in $\mathrm{CO} 2$ emissions (pollutant) is calculated as:

$$
\mathrm{e}=\widehat{\mathrm{ELf}}
$$

where $\mathrm{E}$ is an $\mathrm{nxn}$ diagonal matrix defining $\mathrm{CO} 2$ emissions released to environment by producing 1.00 monetary unit output by sector, and $\mathrm{e}$ is an $\mathrm{nx} 1$ column vector of emissions by each sector.

Equation (3) denotes $\mathrm{CO} 2$ emissions released by each sector and we decompose final demand into three components that measure final demand structure $\left(f_{d}\right)$, per capita expenditure $\left(f_{e}\right)$ and population $\left(f_{p}\right)$ :

$$
\begin{gathered}
e=\widehat{E} L f=\widehat{E} L f_{d} f_{e} f_{p} \\
f_{d}=f\left(\iota^{\prime} f\right)^{-1} \\
f_{e}=\iota^{\prime} f P^{-1} \\
f_{p}=P
\end{gathered}
$$

$f_{d}$ is an $n \times 1$ vector whose elements are $f_{i} / \sum f_{i}, f_{e}$ is a number whose elements are $\sum f_{i} / P$, and $f_{p}$ equals to $P$, population, which is a number.

The change in $\mathrm{CO} 2$ emissions in additive SDA, using these five factors changes can be written as follows:

$$
\Delta \mathrm{e}=\Delta \mathrm{E}+\Delta \mathrm{L}+\Delta \mathrm{f}_{\mathrm{d}}+\Delta \mathrm{f}_{\mathrm{e}}+\Delta \mathrm{f}_{\mathrm{p}}
$$

We use the average polar decomposition technique of Dietzenbacher and Los to decompose changes in emissions as below:

$$
\begin{gathered}
\Delta e=\frac{1}{2}(\Delta E)\left[L^{0} f_{d}^{0} f_{e}^{0} f_{p}^{0}+L^{1} f_{d}^{1} f_{e}^{1} f_{p}^{1}\right]+\frac{1}{2}\left[E^{0} \Delta L f_{d}^{1} f_{e}^{1} f_{p}^{1}+E^{1} \Delta L f_{d}^{0} f_{e}^{0} f_{p}^{0}\right]+\frac{1}{2}\left[E^{0} L^{0} \Delta f_{d} f_{e}^{1} f_{p}^{1}+E^{1} L^{1} \Delta f_{d} f_{e}^{0} f_{p}^{0}\right] \\
+\frac{1}{2}\left[E^{0} L^{0} f_{d}^{0} \Delta f_{e} f_{p}^{1}+E^{1} L^{1} f_{d}^{1} \Delta f_{e} f_{p}^{0}\right]+\frac{1}{2}\left[E^{0} L^{0} f_{d}^{0} f_{e}^{0}+E^{1} L^{1} f_{d}^{1} f_{e}^{1}\right] \Delta f_{p}
\end{gathered}
$$


It should be noted that our data is in SUT format, it is not IO. Multiplier equation should be transformed to be applied to SUT formatted tables. L matrix and $f$ vector are required to be computed from the SUT table and this is not a trivial transformation. The steps of the transformation are available upon request.

\section{RESULTS AND DISCUSSION}

\subsection{Analysis of $\mathrm{CO} 2$ Emissions}

Figure 2 shows trends of the highest nine CO2 emitting sectors (according to 2015 emissions), and GDP, population, and GDP per capita values in the 25-year period. In general, emissions increases were higher in 1995-2000, 2005-2010, and 2010-2015 periods. When GDP values are reviewed for the same period, it seems that growth rates were high between 2000-2010, and reached an even higher rate between 2010-2015. Population growth was stable during these 25 years. As for GDP per capita, it grew high in 2000-2005, and recorded a much higher growth rate in 2010-2015. It seems that emissions increase does not have exactly the same course with population, GDP, or GDP per capita. Looking into sectors one by one, energy takes the first place again, it has been in an increasing trend since 1990, but its contribution has increased even more especially since 2005. Land transportation made a significant contribution in 2005-2015, and it recorded $17 \%$ of total emissions. Mineral sector has always ranked the $3 \mathrm{rd}$ and it has been in an upward trend after 2005. Food and Textile sectors ranked the 4th and 5th in contribution to CO2 emissions in 1990-1995, showed an increasing trend until 2005, but Coke, Refined Petroleum Products and Nuclear Fuels replaced them and became the 4th largest contributor after then. Although Service sector's contribution is small, only 3\% in 2010-2015, it draws attention as it has an increasing trend after 2005. Water Transportation and Air Transportation have always increased their contributions but they remained the 8th and 9th sectors in contribution to emissions. Extraction of Petroleum and Natural Gas is a high emitting sector due to its fugitive CO2 emissions, but as its contribution to total emissions remained relatively low in Turkey, it is not given separately in Figure 2 . Metal, Chemistry, and Rubber and Plastic sectors are other high $\mathrm{CO} 2$ emitting sectors due to emissions from fuel combustion and from manufacturing processes in production, but again, due to their relatively low contributions to Turkey's emissions, they are given in the Aggregated Others sector in Figure 2. 


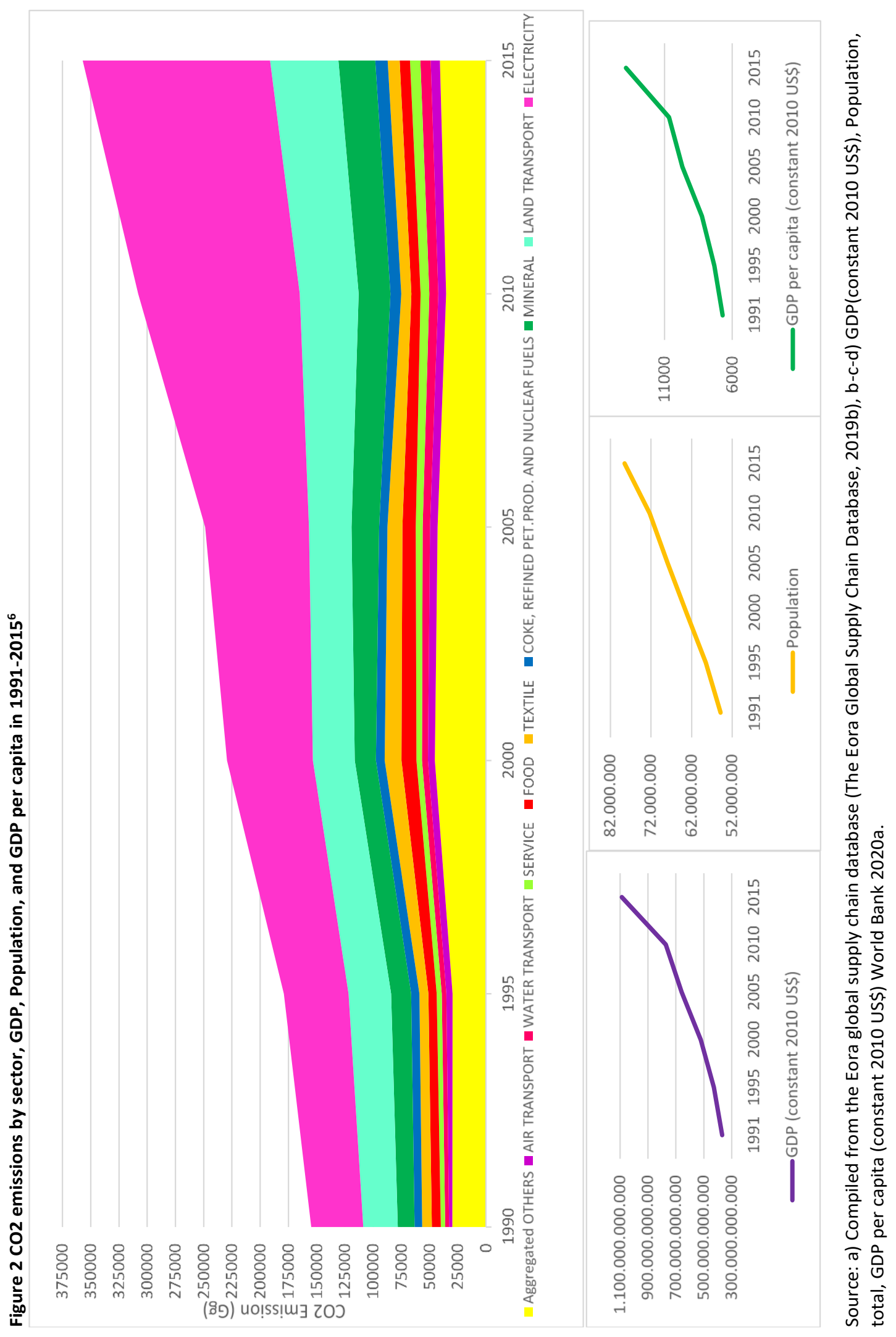




\subsection{Drivers of $\mathrm{CO} 2$ Emissions Change}

The findings of the decomposition analysis provide insights into the causes of increase in Turkish CO2 emissions in the period 1990-2015 in five-year intervals. Influences of 5 different factors, namely emission coefficient, technology, final demand structure, per capita expenditure, and population were computed. The decomposition results are shown in Figure 3.

When 25-year emissions increase is considered, both emission coefficient and technology were the curbing factors. Reduction in emission coefficients $(\Delta \mathrm{e})$ avoided $289,998 \mathrm{Gg} \mathrm{CO} 2$ emissions alone ($143.28 \%$ of net $\mathrm{CO} 2$ emissions change). Technological development $(\Delta \mathrm{L}$ ) provided $5,483 \mathrm{Gg} \mathrm{CO} 2$ emissions reduction $(-2.71 \%)$. Final demand structure effect was so small, but provided $226 \mathrm{Gg} \mathrm{CO} 2$ emissions reduction $(-0.11 \%)$. These reductions were offset and reversed by the changes in per capita expenditure $(\Delta \mathrm{fe})(411,862 \mathrm{Gg} \mathrm{CO} 2,+203.48 \%)$, and population $(\Delta \mathrm{fp})(86,250 \mathrm{Gg} \mathrm{CO} 2,+42.61 \%)$, and net $\mathrm{CO} 2$ emissions increase was $202,406 \mathrm{Gg}$ in 25 -year period. Per capita expenditure was the most influencing factor resulting an actual increase in emissions, and population was the second driver of emissions growth. The reductions driven by emission coefficients and technology can be interpreted as Turkey made some progress in switching to a less carbon intensive production system.

Increasing effect of final demand to overall $\mathrm{CO} 2$ emissions change shows that the real determinant is the consumption side of the economy. The contribution of consumption is 1.69 times greater than the contribution of production. Per capita expenditure turned out to be the primary increasing factor, and increasing effect of population was significative as expected due to continuous increase in population. 


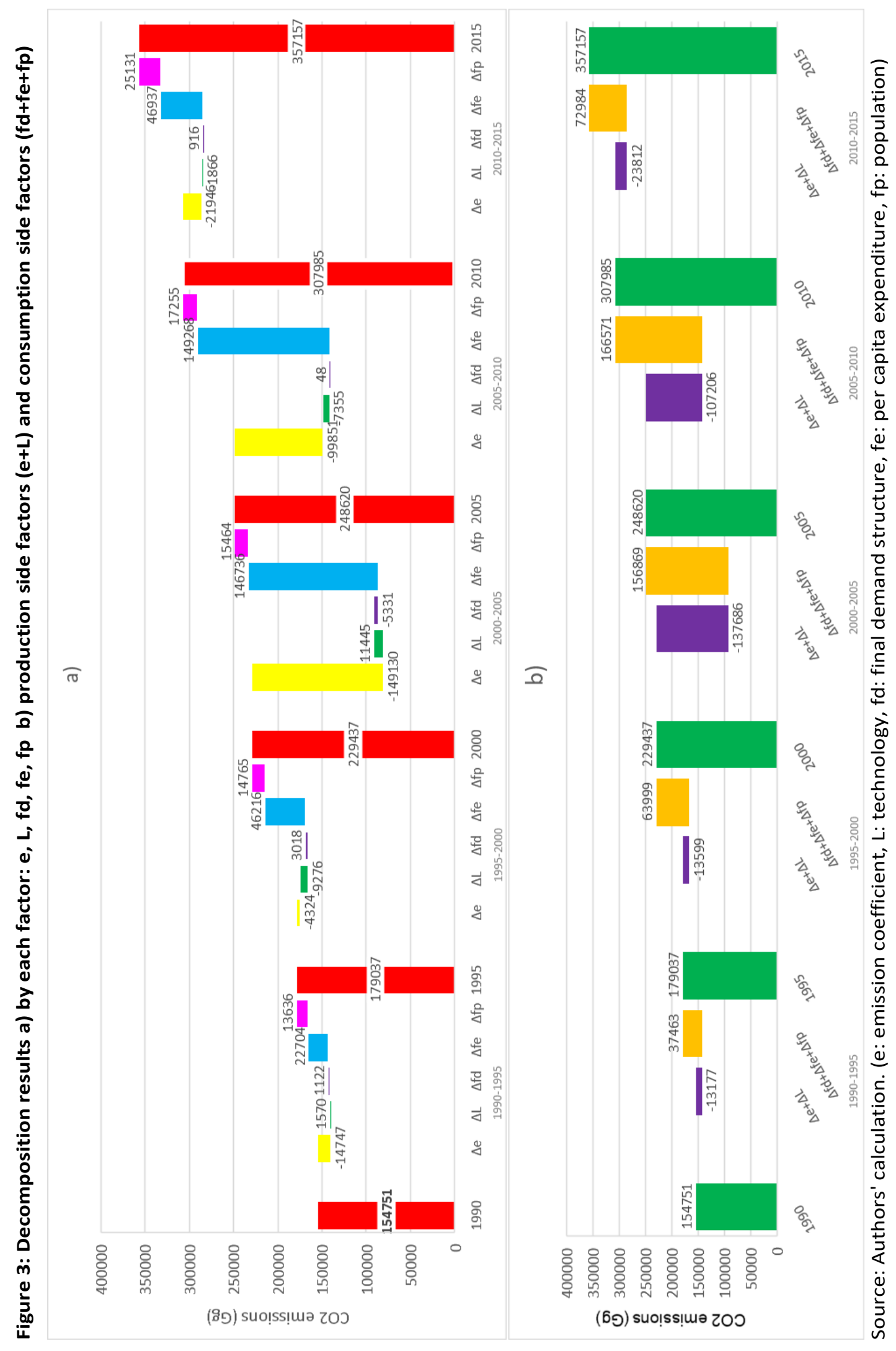


The first part of equation (5) gives $\mathrm{CO} 2$ emissions change due to change in emission coefficient (e). The results in the $\Delta \mathrm{e}$ column shows a decisive trajectory, changes in emission coefficient have always decreased emissions even though the magnitudes of its effect have changed from one period to the other.

Emission coefficients can also refer to carbon intensity of the economy. Environmental awareness and sensitivity to environmental problems in Turkey, partly due to the EU accession process, has reached the highest level in the 2000s. Turkey started EU accession negotiations in 2005 and started to introduce new legislature to harmonize its legal system with that of the EU. Environmental regulations were passed largely due to this impetus. Between 2003 and 20052 new laws, 5 new regulations, 1 communiqué and 3 circulars related to environmental protection came into force ${ }^{7}$. In the next 5-year interval 22 new regulations, 14 circulars and 12 communiqués were introduced and the Environment Chapter, Chapter 27, was also opened for negotiations in 2009. But, the influence of EU accession process decreased in 2010 s due to a variety of facts; cooperation on migration, the rule of law, and independence of judiciary. There is still an on-going dialog on opened but not closed 16 Chapters out of 35 .

$\Delta \mathrm{L}$ shows the effects of production technology on emissions change. The changes in technology usually resulted in decrease in emissions, except the periods 1990-1995 and 2000-2005. Decreasing effect of production technology in emissions change must be due to continuous development in production technology.

Despite attending some of the first international climate change meetings even before establishment of the UNFCCC, Turkey's politics can be defined as a perfect inaction in 1990-2000 period. This stance was altered marginally in 2001, with the removal of Turkey's name from Annex 2 (it had been listed due to being an OECD country) and the acceptance of its special circumstances among other parties in Annex 1. Turkey acceded to the UNFCCC in 2004, exactly twelve years after its establishment. And at the same time, since Turkey did not sign the Kyoto Protocol in 2005, it did not have an emissions reduction target in this period. These delays refrained Turkey from increasing its institutional capacity for climate change in these early stages.

Turkey submitted its first national GHG emissions inventory to the UNFCCC in 2006 and prepared its first National Communication on Climate Change in 2007. Turkey published its first climate change documents between 2010-2012 ${ }^{8}$. Boosting energy efficiency projects and renewable energy investments were the outstanding targets in these documents. In addition to these documents, solely energy focused papers ${ }^{9}$ were also prepared not only for environmental protection but also to reduce energy dependency rightfully recognized as a threat to economic and political volatility for Turkey.

Energy intensity levels continuously decreased since 1990 (0.09), and reached 0.07 tonne of oil equivalent (toe) / thousand 2010 USD in 2015 (Total primary energy supply by GDP (PPP)- IEA, 2019). Renewable energy supply was 9.7 million tonnes of oil equivalent (Mtoe) in 1990, 10.1 Mtoe in 2000, and 15.9 Mtoe in 2015 (Biofuels and waste: 3.2 Mtoe, Hydro: 5.8 Mtoe, Wind-Solar-Geothermal: 6.9 Mtoe) (Total primary energy supply by source- IEA, 2019). But, the share of renewables in total energy supply remained the same, around $12 \%$ of total primary energy supply, due to hugely increased energy demand. Turkey intends to reach a total capacity of $61 \mathrm{GW}$ (45.95 Mtoe maximum annual power production) by 2023 (Biofuels and waste: $1 \mathrm{GW}$ ( 0.75 Mtoe), Hydro: $34 \mathrm{GW}$ (25.61 Mtoe), Geothermal: $1 \mathrm{GW}$ (0.75 Mtoe), Solar: $5 \mathrm{GW}$ (3.77 Mtoe), Wind: $20 \mathrm{GW}$ (15.06 Mtoe)) [Republic of Turkey, 2017]. Negative contributions of technological changes in three 5-year periods (1995-2000, 2005-2010, 2010-2015) should be related to the success in energy efficiency projects but cannot be related to increase in renewable energy supply as use of fossil fuel resources offset it. Among fossil fuel resources, coal which has a very high $\mathrm{CO} 2$ emission, started to increase its share steeply after 2005, oil decreased its share continuously after 1995, and natural gas started to increase its share after 1995 and its use almost doubled since 2005. If coal supply could have been changed with renewable energy since 1990, negative contribution of technology factor might have been greater. 
The final demand structure effect, $\Delta \mathrm{fd}$, is the third factor analyzed and its influence on emissions was the smallest.

Per capita expenditure acted to increase to emissions in all periods. Especially after 2000s, the effect was great. The Turkish economy witnessed a deep economic crisis in 2001 and had to undertake many financial and economic reforms under the watchful eye of the IMF. It was also a period, when moderate political Islam was believed to be able solve the terrorism threats the fundamentalist Muslims posed. The new Turkish government, elected after and under the shadow of the 2001 economic crisis, was well-positioned to play an influential role towards this goal. The EU accession negotiations started in this climate and the years leading up to as well as the subsequent years were a time of positive expectations for Turkey and by the Turkish society. The international economic environment was also favorable with a weak dollar and a strong Turkish lira and Turkey easily borrowed from abroad. The effect of the 2008 global financial crisis on Turkey was relatively minor. After a negative growth rate of 5 percent in 2009, Turkey re-embarked on a path of growth. These economic conditions fueled domestic consumption and led to a rapid increase in per capita expenditure.

In all of the periods, the change in population, $\Delta \mathrm{fp}$, increased $\mathrm{CO} 2$ emissions increase and it followed a continuously increasing path. As the population of Turkey was increasing during these years, positive contribution of population is expected.

The results of 59 sectors were aggregated into 23 sectors by the authors according to their contributions to growth, export, employment, and emissions, and according to their energy dependence. The sectoral mapping can be provided upon request.

Figure 4 presents the decomposition results for sectors. 


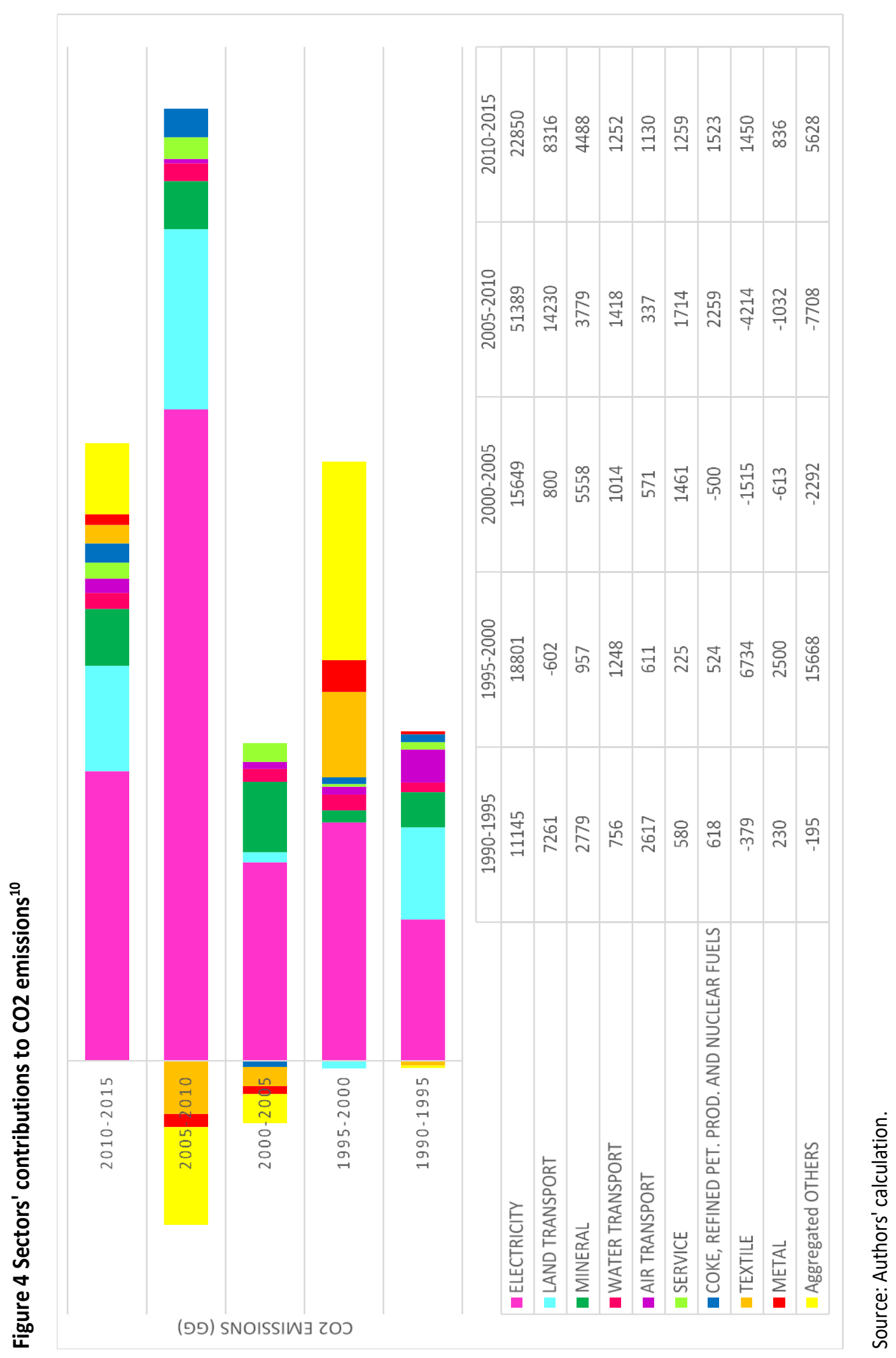


Electricity, Land Transportation, and Mineral are the most important sectors that explain $\mathrm{CO} 2$ emissions increase. It is noteworthy that Electricity recorded more than half of the total $\mathrm{CO} 2$ emissions increase, especially in the 2005-2010 period as seen in Table 2. Turkey's population is growing and the standard of living is improving with time and technology. Since electricity consumption is an indicator of development and growth, some positive contribution over the time period under analysis is to be expected. Turkey's environmental protection policies should be considered in their infancy for most of the 25-year period although important measures for energy efficiency were taken. Nevertheless, the large contribution of electricity in the 2005-2010 period is discouraging. We argue that this is largely due to the increased capacity of coal-fired power plants. Electricity production from coal-fired power plants increased by 27 percent in this period compared to a 13 percent increase in the preceding period (Electricity generation by source- IEA, 2019). In the following period, 2010-2015, electricity from coal-fired power plants increased by 38 percent (IEA, 2019) but Turkey signed the Kyoto Protocol in 2009 and as part of the harmonization process with the EU, two important regulations regarding air quality passed around the same time. More care about environmental pollution was thus given when capacity was increased in the subsequent 5-year interval. However, the increase in coal-fired electricity production in 2015-2018 has reached 49 percent (IEA, 2019) so the electricity generation sector has likely continued to be a major contributor to CO2 emissions after 2015.

Land transport sector was the second in contribution to $\mathrm{CO} 2$ emissions increase with a $14.82 \%$ rate in this 25 -year period. Car ownership in Turkey has risen sharply in the 25 years analyzed. Annual new motor vehicle registrations were below 200,000 at the beginning of the period but had reached almost 750,000 by 2015 . In 1997, LPG (autogas) which is considered to be cleaner than gasoline and diesel started to be used in automobiles. Today, Turkey is the first in Europe and second in the world as far as the number of automobiles with LPG are concerned. This was one factor that kept emissions due to increased car ownership in check initially because by 1997 annual new motor vehicle registrations had reached 300,000 . In the period from 2000-2005 the effect of the 2001 economic crisis was significant and new motor vehicle registrations had dropped to 70,000 in 2002. During 2005 and 2010 period, the change in emissions due to land transportation is quite large. New motor vehicle registrations during this period is 1.9 million, close to 400,000 per annum on average. In 2013 and 2014, tax incentives were given to retire automobiles that were older than 20 years which resulted in retiring 400,000 older vehicles from traffic. Even though new automobile registrations continued to rise and had reached an annual average of 631,000 , the increase in emissions was almost half as much as the previous period. About half the motor vehicles on the road are automobiles and the average number of road motor vehicles in Turkey has increased from around 5 million in the 1990-1995 period to 18 million by the 2010-2015 period.

The increases in Mineral sector's emissions (2.17 times of 1990 levels in 2015) and Metal sector's emissions (1.46 times of 1990 levels in 2015) are principally due to growth in emissions associated with cement production and iron and steel production, and emissions from producing these goods increased because of the industrial growth and the increased demand for construction materials. Mineral industry produces cement, lime, glass, ceramic, and non-metallurgical magnesia products, and cement production emits $86.5 \%$ of $\mathrm{CO} 2$ emissions of total Mineral sector emissions. Calcination process and fuel combustion for heating are the processes where $\mathrm{CO} 2$ is emitted.

Water Transport was the fourth, and Air Transport was the fifth in contribution to $\mathrm{CO} 2$ emissions. Air Transport, whose emission coefficient is well above even Land Transport, recorded an increase of $1229 \%$ in passenger transport and $920 \%$ in freight transport in 1990-2015 period, and increased its growth rate especially after 2000s. Coke, Refined Petroleum, and Nuclear Fuels sector grew in 2005-2015 years and its contribution to emissions increased as well. Raw materials are processed in this sector, and refinery processing of petroleum dominates this sector in Turkey. Fuels, heating oils, lubricating oils, asphalt, and petrochemical materials are the products of this sector, and these products are used by energy and transportation sectors. 


\section{CONCLUSION AND POLICY IMPLICATIONS}

In this study, CO2 emissions in five year intervals between 1990 and 2015 were decomposed into 5 factors; emission coefficient, technology, final demand structure, per capita expenditure, and population, by employing the SDA method. The results indicated that the key driving force responsible for promoting CO2 emissions in Turkey from 1990 through 2015 was per capita expenditure, especially after 2000s, while emission coefficient was the most significant factor in inhibiting emissions. Population was significant and had a restraining effect on emissions increase as well.

These results are quite similar to the results of recent decomposition studies conducted for the whole world, for UMI countries and for Turkey. As the results shows, CO2 emissions increased due to consumption activities and consumption is the main determinant of emissions in Turkey. Mitigating effect of production factors fell pretty behind the increasing effect of consumption factors.

The actions in Turkey's INDC included only a few measures on consumption, these were to promote public transport, construct energy efficient buildings, promote recycling. However, this study shows that consumption activities present the greatest potential for improvements.

Electricity, Land Transportation, Mineral, Air Transportation, Coke, Refined Petroleum and Nuclear Fuels and Metal sectors were found the most contributing sectors to $\mathrm{CO} 2$ emissions increase and electricity dominated this increase with recording more than half of net emission. When energy actions in the INDC were considered, utilization of all coal reserves seems inadmissible, instead, Turkey should prioritize speeding up renewable energy investments and continuing energy efficiency measures, the actions already listed in the INDC. Carbon taxation in electricity and oil consumption can decrease personal demand for these products and as a consumer-oriented policy, it can seriously contribute to the measures taken on the production side. Promoting public transport action in the INDC should be the top priority target in Land Transportation due to the sharp rise in car ownership, and this can be only achieved in case of increasing people's access to public transportation. Use of clean fuels and vehicles is also a good measure and needs to be highly subsidized for rapid dissemination. Directing investments from air to rail transport and water transport (where possible) will increase the share of these modes and decrease the emissions due to much lower emission coefficients. Slowing down the construction sector can restrain emissions increase from Mineral, Metal and also from Coke, Refined Petroleum and Nuclear Fuels sectors to a great extent. Making acquisition an energy certificate mandatory for new buildings can be a good policy for both commercial and residential buildings.

Guiding consumers to change their consumption behavior through measures such as strengthening education and rising public awareness is an urgent necessity for reducing demand for high emitting products and services. Consumers informed about highly emitting products can put pressure on producers to reduce emissions during production or to produce alternative products. Consumers with increased knowledge about emissions will reduce consumption and disposal, change their use and disposal behavior and will tend to buy more efficient products, and thereby, they will switch to a low-carbon life style.

Stating its intention as to contribute to collective efforts to fight against climate change, Turkey needs to reconcile its development with $\mathrm{CO} 2$ emissions mitigation. Following the EU example which stabilized its emissions starting in 2000s and reduced since 2006 and China example which accomplished plateauing its emissions in the recent decade, Turkey can shift to a low-carbon development paradigm. But, existing economic problems that are deepening due to Covid 19 pandemic indicates a lower capability to decarbonize its economy. At this point, Turkey's efforts to be eligible for financial support gain importance but it seems unlikely due to weaknesses in its INDC and failure to take serious measures after 2015. First, Turkey should revise its emissions target by determining an actual year as reference year (e.g. USA, EU, India, Russia) or by stating a peak time for emissions (e.g. China) to increase admissibility of the target. Revising and prioritizing the actions to be put forward to achieve this target, including emissions mitigation potentials of these actions, and adding implementation plans will be to Turkey's benefit. Second, the actions to reduce emissions should not be postponed any longer, and the existing investment 
plans across the country should be revised by taking emissions into account. Zero- and low-cost reducing actions should be implemented immediately.

Two aspects related to the topic that are not included in this study deserve investigation in future studies. First, instead of decomposing only $\mathrm{CO} 2$ emissions, all GHGs can be included. As sectoral GHG emissions provided in the Eora database did not match actual emissions well, but $\mathrm{CO} 2$ emissions were very consistent with actual $\mathrm{CO} 2$ emissions, this gas was selected for our study. Second, analyzing import and export emissions trends and the factors behind these emissions will increase our knowledge on this subject. Such an analysis requires different methodological choices than adopted in our study.

\section{NOTES}

${ }^{1}$ Annex 1 Parties submit their Biennial Reports (BRs) to the UNFCCC Secretariat every 2 years, and the Fourth BR should be submitted by 1 January 2020.

${ }^{2}$ Annex 1 Parties submit their National Communications (NCS) to the UNFCCC Secretariat every four years and the Seventh NC should be submitted by 1 January 2018.

${ }^{3}$ Figure 1 panel a) UMI, HI, EU, China, USA graphs use values on left y axis; Turkey, Russia, India graphs use values on right y axis; panel (c) Agriculture and Waste sectors $\mathrm{CO} 2$ emissions bars cannot be seen because of their relatively low emissions.

${ }^{4}$ Methods for understanding driving forces behind an aggregate indicator are decomposition analysis and econometric techniques. Decomposition analysis provides better understanding of systems and dominates this literature. It distributes a change in an indicator into its components. The main decomposition methods are index decomposition analysis (IDA) and structural decomposition analysis (SDA). IDA relates a change on an aggregate to activity level (of an industry), SDA relates to input output model (whole economic system). IDA is flexible in formulation but covers only the direct effects. SDA is more data intensive and observes direct and indirect demand effects which defines that demand change in one sector indirectly lets changes in demand of others. Productiontheoretical approach (PDA) is another decomposition method based on production theory, which is named as such and proposed for energy or environment related decompositions in Zhou and Ang (2008). Data requirements are even lower than IDA. Zhou and Ang (2008) provide a comparison between PDA, IDA and SDA. Econometric studies can also be used to identify the drivers based on the IPAT identity of Ehrlich and Holdren (1971) and its subsequent modifications, especially, STIRPAT. However, by construction these models are also aggregate in nature and cannot provide the rich sectoral detail SDA analysis can.

${ }^{5}$ Energy intensity is a factor generally used in studies employing IDAs and defines energy consumption per GDP.

${ }^{6}$ The first nine sectors with highest emissions were included separately and the remaining fourteen sectors were aggregated and titled "Aggregated Others". $\mathrm{CO} 2$ emissions from 23 sectors can be provided upon request.

${ }^{7}$ For laws go to https://cygm.csb.gov.tr/kanunlar-i-438; for regulations go to https://cygm.csb.gov.tr/yonetmelikleri-440; for circulars go to https://cygm.csb.gov.tr/tebligler-i-441; for communiqués go to https://cygm.csb.gov.tr/genelgeler-i-442

${ }^{8}$ For National Strategy for Climate Change (NCCS) (2010-2020), National Climate Change Adaptation Strategy and Action Plan, National Climate Change Action Plan (NCCAP) go to http://www.dsi.gov.tr/docs/iklim-degisikligi/

${ }^{9}$ For The Energy Efficiency Law No. 5627 go to https://www.resmigazete.gov.tr/eskiler/2007/05/20070502-2.htm; for National Renewable Energy Action Plan (NREAP) 2017-2023 go to https://www.resmigazete.gov.tr/eskiler/2018/01/20180102M1-1-1.pdf; for Energy Efficiency Strategy Paper 20122023 and National Energy Efficiency Action Plan (NEEAP) 2017-2023 go to http://www.yegm.gov.tr; for Electric Energy Market and Security of Supply Strategy Paper go to https://www.eigm.gov.tr

10 The first nine sectors contributing to $\mathrm{CO} 2$ emissions increase were given separately and the remaining fourteen were aggregated and titled "Aggregated Others". Decomposition results for 23 sectors are available upon request. 


\section{AUTHOR STATEMENT}

\section{Research and Publication Ethics Statement}

This study has been prepared in accordance with the ethical principles of scientific research and publication.

\section{Author Contribution}

Ayla Alkan: Research Idea Generation/ Research Design/ Literature Review/ Methodology / Data Collection /Data Analysis/Writing/Review and Editing.

Ayla Oğuş Binatlı: Research Idea Generation / Research Design / Data Collection / Writing / Review and Editing.

\section{Conflict of Interest}

There is no conflict of interest arising from the study for the authors or third parties.

\section{REFERENCES}

Acar, S., A. A. Aşici, O. Balaban, M. B. Berke, İ. Çakmak, S. C. Mazlum, G. N. Demirer, P. İpek, B. Kat, V. Kulaçoğlu, I. Kurnaz, Ü. Şahin, R. Sari, U. Soytaş, F. Taşkin, E. Turhan, B. Ünüvar, E. Voyvoda, B. V. Özenç, A. E. Yeldan, A. Yilmaz, i. Yücel (2016), Addressing Climate Change from an Economic Policy Perspective, TÜSIAD Publication No: T/2016, 12-583, Istanbul: TUSIAD.

Akbostancı, E., G. İ. Tunç, S. Türüt-Aşık (2018), "Drivers of fuel based carbon dioxide emissions: The case of Turkey" Renewable and Sustainable Energy Reviews, 81, 2599-2608.

Alkan, A., A. Oğuş-Binatlı, Ç. Değer (2018), “Achieving Turkey's INDC Target: Assessments of NCCAP and INDC Documents and Proposing Conceivable Policies", Sustainability, 10(6), 2-27.

Arto, I., E. Dietzenbacher (2014), "Drivers of The Growth in Global Greenhouse Gas Emissions", Environmental Science \& Technology, 48(10), 5388-5394, DOI: 10.1021/es5005347.

Bierbaum, R. M., M. Fay, B. Ross-Larson (2009), World Development Report 2010: Development and Climate Change, Washington, DC: World Bank Group,

http://documents.worldbank.org/curated/en/201001468159913657/World-development-report-2010development-and-climate-change.

Chang, C., M. Dong, B. Sui, Y. Chu (2019), “Driving Forces of Global Carbon Emissions: From Time-and Spatial-Dynamic Perspectives", Economic Modelling, 77, 70-80, DOI: 10.1016/j.econmod.2019.01.021.

Dong, K., H. Jiang, H. Sun, X. Dong (2019), “Driving Forces and Mitigation Potential of Global CO2 Emissions from 1980 through 2030: Evidence from Countried with Different Income Levels", Science of The Total Environment, 649, 335-343.

Ehrlich, P. R., J. P. Holdren (1971), "Impact of Population Growth", Science, 171(3977), 1212-1217.

Henriques, S. T., K. J. Borowiecki (2017), "The Drivers of Long-run CO2 Emissions in Europe, North America and Japan since 1800", Energy Policy, 101, 537-549, DOI: 10.1016/j.enpol.2016.11.005.

International Energy Agency (IEA) (2019), IEA Data and Statistics. https://www.iea.org/data-and-statistics, Accessed on: 01.01.2019.

Isik, M., K. Sarica, I. Ari (2020), "Driving forces of Turkey's Transportation Sector CO2 Emissions: An LMDI Approach", Transport Policy, 97, 210-219.

Karakaya, E., A. Bostan, M. Özçağ (2019), “Decomposition and Decoupling Analysis of Energy-Related Carbon Emissions in Turkey", Environmental Science and Pollution Research, 26, 32080-32091.

Karapinar, B., H. Dudu, O. Geyik, A. M. Yakut (2019), "How to Reach an Elusive INDC Target: Macro-Economic Implications of Carbon Taxation and Emissions Trading in Turkey", Climate Policy, 19(9), 1157-1172, DOI: 10.1080/14693062.2019.1635875. 
Kat, B., S. Paltsev, M. Yuan (2018), “Turkish Energy Sector Development and the Paris Agreement goals: A CGE Model Assessment", Energy Policy, 122, 84-96, doi: 10.1016/j.enpol.2018.07.030.

Kim, H., M. Kim, H. Kim, S. Park (2020), “Decomposition Analysis of CO2 Emission from Electricity Generation: Comparison of OECD Countries before and after the Financial Crisis", Energies, 13, 3522, doi:10.3390/en13143522.

Köne, A. Ç., T. Büke (2019), "Factor Analysis of Projected Carbon Dioxide Emissions According to the IPCC Based Sustainable Emission Scenario in Turkey", Renewable Energy, 133, 914-918.

Perrier, Q., C. Guivarch, O. Boucher (2019), "Diversity of Greenhouse Gas Emission Drivers across European Countries since the 2008 crisis", Climate Policy, 19(9), 1067-1087, DOI: 10.1080/14693062.2019.1625744.

Republic of Turkey (2015), Intended Nationally Determined Contribution. http://www4.unfccc.int/submissions/INDC/Published\%20Documents/Turkey/1/The INDC of TURKEY v.1 5.19.30.pdf, Accessed on: 11.11.2019.

Republic of Turkey (2017), National Renewable Energy Action Plan (NREAP) 2017-2023. https://www.resmigazete.gov.tr/eskiler/2018/01/20180102M1-1-1.pdf, Accessed on: 11.11.2019.

Sesso, P. P., S. F. Amancio-Vieira, I. D. Zapparoli, U. A. Sesso Filho (2020), "Structural Decomposition of Variations of Carbon Dioxide Emissions for the United States, the European Union and BRIC", Journal of Cleaner Production, 252, 119761, DOI: 10.1016/j.jclepro.2019.119761.

The Eora Global Supply Chain Database (2019a), Carbon Footprint of Nations/ national.cba.report.1970.2015.txt. https://worldmrio.com/footprints/carbon/, Accessed on: 01.09.2019.

The Eora Global Supply Chain Database (2019b), National IO Tables. https://worldmrio.com/countrywise/, Accessed on: 01.05.2019.

Turkish Statistical Institute (2017), National Greenhouse Gas Inventory Report 1990-2015, Annual Report for submission under the "United Nations Framework Convention on Climate Change. https://unfccc.int/process-and-meetings/transparency-and-reporting/reporting-and-review-under-theconvention/greenhouse-gas-inventories-annex-i-parties/submissions/national-inventory-submissions2017, Accessed on: 20.12.2019.

Turkish Statistical Institute (2021), Total Passenger and FReight Traffic at the Airports, Statistic Data Portal. https://data.tuik.gov.tr/Kategori/GetKategori?p=ulastirma-ve-haberlesme-112\&dil=1， Accessed on: 24.01.2021.

UNFCCC (2016), Paris Agreement. https://unfccc.int/process-and-meetings/the-paris-agreement/the-parisagreement, Accessed on: 22.02.2020.

UNFCCC (2020), GHG data from UNFCCC, Time Series-Annex 1. https://di.unfccc.int/time series, Accessed on: 01.07.2020.

World Bank (2020a), World Development Indicators, World Bank Databank. https://databank.worldbank.org/source/world-development-indicators, Accessed on: 01.08.2020.

World Bank (2020b), Country and Lending Groups-By income. https://datahelpdesk.worldbank.org/knowledgebase/articles/906519-world-bank-country-and-lendinggroups, Accessed on: 01.09.2020.

Xia, Q., H. Wang, X. Liu, X. Pan (2020), "Drivers of Global and National CO2 Emissions Changes 2000-2017", Climate Policy, DOI: 10.1080/14693062.2020.1864267.

Zheng, J., Z. Mi, D. Coffman, Y. Shan, D. Guan, S. Wang (2019), "The Slowdown in China's Carbon Emissions Growth in The New Phase of Economic Development", One Earth, 1(2), 240-253, DOI: 10.1016/j.oneear. 2019.10.007.

Zheng, X., Y. Lu, J. Yuan, Y. Baninla S. Zhang, N. C. Stenseth, D. O. Hessen, H. Tian, M. Obersteiner, D. Chen (2020), "Drivers of Change in China's Energy-Related $\mathrm{CO} 2$ Emissions", Proceedings of the National Academy of Sciences, 117(1), 29-36, DOI: 10.1073/pnas.1908513117.

Zhou, P., B. W. Ang (2008), "Decomposition of aggregate CO2 Emissions: A Production-Theoretical Approach", Energy Economics, 30, 1054-1067. 